\title{
PENGEMBANGAN PASAR EKSPOR LADA INDONESIA
}

\section{Development of Indonesian Pepper Export Markets}

\author{
Ely Nurhayati, Sri Hartoyo, Sri Mulatsih \\ Institut Pertanian Bogor, JI. Raya Darmaga, Bogor, Jawa Barat 16680, Indonesia \\ Email: haya.jundullah@gmail.com
}

\begin{abstract}
Naskah diterima: 05/07/2018; Naskah direvisi: 10/09/2018; Disetujui diterbitkan: 03/12/2018
Dipublikasikan online: 31/12/2018
\end{abstract}

\begin{abstract}
Abstrak
Salah satu komoditas yang dapat dimanfaatkan untuk meningkatkan kinerja ekspor Indonesia sebagai negara agraris adalah lada. Penelitian ini bertujuan untuk menganalisis pasar potensial untuk ekspor lada yang bisa dikembangkan, serta mengetahui faktor-faktor yang memengaruhi ekspor komoditas lada. Penelitian ini menggunakan metode RCA, EPD, XModel, dan Gravity Model. Hasil analisis dengan menggunakan model RCA, EPD, dan Xmodel menunjukkan bahwa 'pasar optimis' untuk dikembangkan adalah Belanda. Sedangkan 'pasar potensial' untuk dikembangkan adalah Malaysia, Vietnam, Korea Selatan, Rusia, Prancis, Belgia, Jerman, dan Amerika Serikat. Sementara itu hasil analisis dengan menggunakan model Gravity menunjukkan bahwa faktor-faktor yang memengaruhi ekspor adalah domestik bruto per kapita, populasi, harga ekspor, jarak ekonomi dan tarif. Oleh karena itu, pemerintah perlu mempertimbangkan faktor-faktor yang memengaruhi ekspor lada untuk mengembangkan pasar ekspor. Faktor tersebut diantaranya menjaga stabilitas harga ekspor, memilih pasar dengan Produk Domestik Bruto (PDB) per kapita yang tinggi, populasi yang besar dan cenderung meningkat, serta memiliki jarak ekonomi dan tarif yang kecil dan cenderung menurun.
\end{abstract}

Kata Kunci: Daya Saing, Ekspor, Lada

\begin{abstract}
Pepper is one of agricultural commodities that has significant export value for Indonesia. The study aims to analyze the potential market for pepper exports that can be developed, and the factors that influence pepper commodity exports. This research used RCA, EPD, X-Model, and Gravity Model methods. Using the RCA, EPD, and X-model the study indicated that the optimistic market' to be developed was the Netherlands. While 'the potential markets' to be developed were Malaysia, Vietnam, South Korea, Russia, France, Belgium, Germany and the United States. Using the Gravity model, it was confirmed factors affected export were gross domestic product per capita, population, export prices, economic distance and tariffs. This study recommends that the Government needs to consider the following factors including the stability of export prices, a market with high Dross Domestic Product (GDP) per capita and a large population which tends to increase, and a small economic distance and tariff that tends to decline.
\end{abstract}

Keywords: Competitiveness, Export, Pepper

JEL Classification: B27, F10, P52, Q17

\section{PENDAHULUAN}

Indonesia negara agraris yang unggul dalam produk pertanian. Salah satu komoditas yang berpotensi meningkatkan ekspor Indonesia adalah rempah-rempah (Kementerian 
Perdagangan RI, 2017). Nilai ekspor rempah Indonesia cenderung berfluktuasi, dan sempat mengalami penurunan di tahun 2004, 2005, 2009 dan 2013. Namun secara umum tren ekspor rempah Indonesia cenderung meningkat dalam 15 tahun terakhir. Nilai ekspor rempah mencapai puncak tertingginya pada tahun 2015, yaitu senilai USD 872,24 ribu.

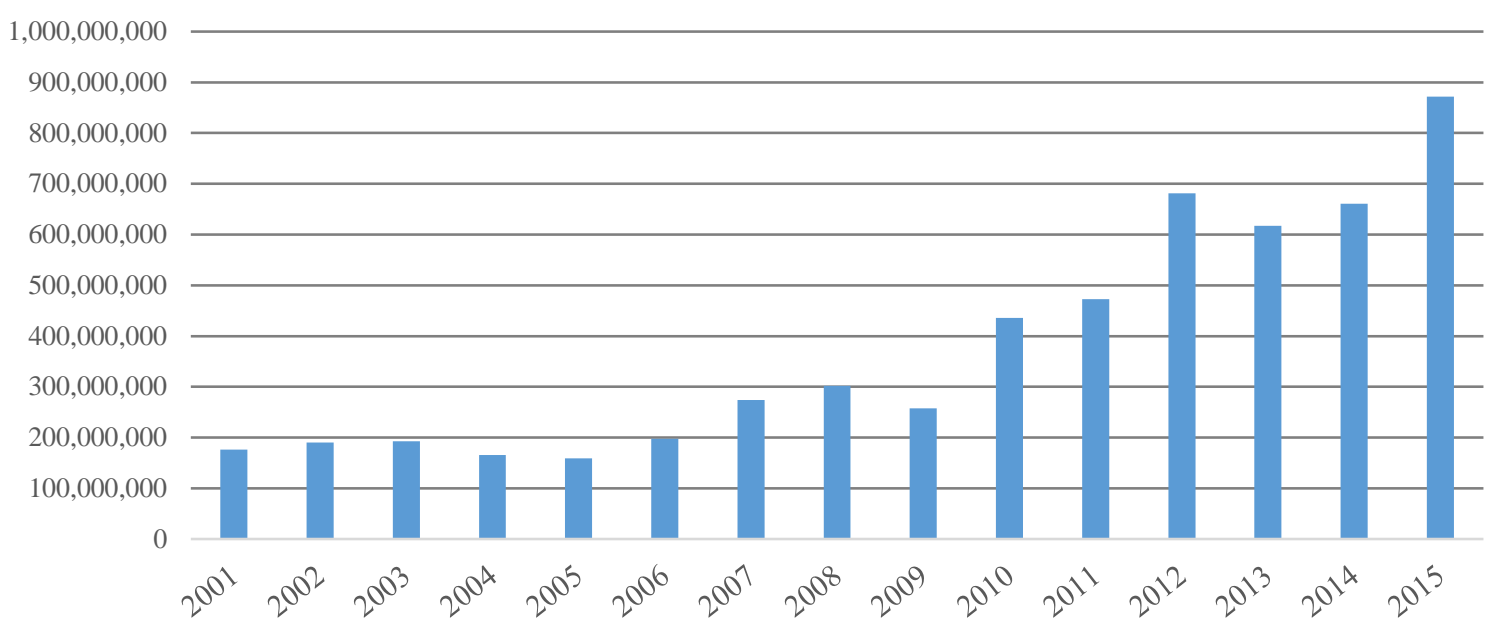

\section{Gambar 1. Nilai Ekspor Rempah Indonesia ke Pasar Dunia (USD)}

Sumber: UN-Comtrade (2018), diolah

Rempah Indonesia adalah salah satu komoditas yang paling banyak diekspor dengan kualitas terbaik di dunia. Diantara banyak komoditas rempah yang dihasilkan, komoditas lada merupakan salah satu komoditas rempah yang dapat dimanfaatkan untuk mengembangkan ekspor.

Lada merupakan tanaman yang memiliki nama Latin Piper Albi Linn, dan masuk dalam kategori biji-bijian. Komoditas ini berbentuk bulat kecil, memiliki rasa yang pedas, pahit, dan hangat. Pada umumnya tanaman lada tumbuh optimal di wilayah yang beriklim tropis pada ketinggian $0-1.000$ meter di atas permukaan air laut. $\mathrm{Di}$ Indonesia, wilayah yang menjadi sentra produksi lada adalah Kepulauan Bangka Belitung, sebagai wilayah dengan produksi lada terbesar. Selanjutnya diikuti oleh Lampung, Sumatera Selatan, Kalimantan Timur dan Sulawesi Selatan. Akumulasi produksi lada di lima provinsi tersebut selama tahun 2010-2014 berkontribusi sebesar $83,70 \%$ dari total produksi lada Indonesia (Kementerian Pertanian RI, 2015). 
Jenis komoditas lada Indonesia yang diekspor merupakan jenis lada putih, lada hitam dan lada lainnya (termasuk lada hijau), baik yang tidak dihancurkan maupun yang dihancurkan dalam bentuk bubuk. Namun demikian struktur ekspor lada Indonesia menunjukkan bahwa lada yang tidak dihancurkan lebih dominan dibandingkan ekspor lada bubuk. Di negara tujuan ekspor, lada terutama dikonsumsi oleh rumah tangga dan digunakan untuk konsumsi langsung pada makanan. Selain sebagai bahan konsumsi langsung, lada juga digunakan untuk konsumsi industri seperti minyak lada, oleorosin lada, industri kesehatan, farmasi dan obat herbal. Adapun lada olahan industri kesehatan dan farmasi banyak digunakan di Eropa dan Amerika, sedangkan olahan lada obat herbal banyak digunakan di negara-negara Asia.

Tahun 2016 Indonesia menjadi eksportir lada terbesar kelima di pasar dunia. Kontribusi ekspor lada Indonesia dalam perdagangan internasional adalah sebanyak 55,15 ribu ton atau setara dengan $5 \%$ dari total ekspor lada dunia. Kompetitor ekspor lada Indonesia di pasar dunia adalah India yang berkontribusi sebanyak 327,83 ribu ton $(29,56 \%)$, Vietnam 182,50 ribu ton $(16,45 \%)$, China 181,26 ribu ton $(16,34 \%)$, dan Spanyol yang mencapai 60,68 ribu ton $(5,47 \%)$ ekspor dunia.

Lada memberikan kontribusi pada devisa negara, karena lada Indonesia lebih unggul bila dibandingkan dengan lada dari negara lainnya. Lada Indonesia merupakan rempah yang sangat khas dan tidak dapat digantikan oleh produk lainnya (Kementerian Pertanian RI, 2013). Di pasar internasional, Indonesia memiliki brand lada khas yang telah lama dikenal dunia, yaitu Lampung black pepper yang merupakan lada hitam yang dihasilkan di Lampung, dan Munthok white pepper yang merupakan lada putih yang dihasilkan di Kepulauan Bangka Belitung. Kedua jenis lada tersebut telah digunakan sebagai acuan standar perdagangan lada dunia (Departemen Pertanian RI, 2009).

Indonesia merupakan salah satu dari lima eksportir lada terbesar di pasar dunia (UN-Comtrade, 2018). Pada tahun 2016 Volume ekspor lada Indonesia ke pasar dunia mencapai 55,14 ribu $\mathrm{kg}$ atau setara dengan $5 \%$ dari total ekspor lada dunia. Besarnya kontribusi ekspor lada Indonesia di 
pasar dunia tersebut menjadi potensi bagi pengembangan ekspor lada.

Selama tahun 2002 hingga 2016 Indonesia telah mengekspor lada secara kontinyu ke 19 negara. Dari 19 negara tersebut, 10 pasar utama yang paling mendominasi ekspor lada Indonesia adalah pasar Malaysia,
Vietnam, Korea Selatan, Rusia, Australia, Prancis, Belgia, Belanda, Jerman dan Amerika Serikat. Selama 15 tahun tersebut volume ekspor komoditas lada Indonesia di pasar tujuan utama mengalami fluktuasi, namun demikian rata-rata pertumbuhannya cenderung positif.

Tabel 1. Volume Ekspor Lada Indonesia ke Sepuluh Pasar Utama (dalam Ton)

\begin{tabular}{|c|c|c|c|c|c|c|c|c|c|c|}
\hline Tahun & Malaysia & Vietnam & Korsel & Rusia & Australia & Prancis & Belgia & Belanda & Jerman & AS \\
\hline 2002 & 557 & 52 & 203 & 237 & 322 & 353 & 28 & 2.378 & 1.290 & 16.285 \\
\hline 2003 & 125 & 1.536 & 113 & 1.281 & 303 & 449 & 69 & 3.107 & 1.943 & 17.738 \\
\hline 2004 & 54 & 379 & 107 & 864 & 451 & 116 & 210 & 1.504 & 1.899 & 11.773 \\
\hline 2005 & 89 & 330 & 234 & 1.094 & 687 & 102 & 279 & 1.945 & 1.577 & 13.211 \\
\hline 2006 & 406 & 1.209 & 20 & 357 & 366 & 362 & 151 & 1.602 & 2.063 & 15.261 \\
\hline 2007 & 617 & 2.207 & 437 & 455 & 274 & 256 & 255 & 2.786 & 2.495 & 17.049 \\
\hline 2008 & 436 & 4.257 & 404 & 546 & 501 & 974 & 293 & 2.635 & 2.338 & 25.405 \\
\hline 2009 & 614 & 5.093 & 480 & 1.090 & 547 & 493 & 203 & 1.778 & 2.093 & 24.805 \\
\hline 2010 & 1.496 & 14.033 & 506 & 1.961 & 930 & 834 & 249 & 2.559 & 2.237 & 25.107 \\
\hline 2011 & 962 & 4.761 & 287 & 205 & 407 & 603 & 135 & 1.426 & 1.321 & 15.298 \\
\hline 2012 & 930 & 17.226 & 265 & 1.659 & 393 & 551 & 224 & 1.972 & 2.265 & 22.923 \\
\hline 2013 & 701 & 12.012 & 122 & 561 & 218 & 980 & 458 & 2.673 & 2.145 & 14.649 \\
\hline 2014 & 639 & 6.118 & 39 & 75 & 198 & 742 & 420 & 1.422 & 2.460 & 6.149 \\
\hline 2015 & 757 & 22.698 & 61 & 176 & 142 & 895 & 409 & 1.895 & 2.866 & 10.114 \\
\hline 2016 & 910 & 19.327 & 357 & 258 & 18 & 1.997 & 58 & 2.808 & 2.296 & 8.540 \\
\hline $\begin{array}{c}\text { Total } \\
\text { Volume }\end{array}$ & 9.293 & 111.238 & 3.635 & 10,819 & 5.757 & 9.707 & 3.441 & 32.490 & 31.288 & 244.307 \\
\hline $\begin{array}{c}\text { Rata-rata } \\
\text { Pertumbuhan } \\
(\%) \\
\end{array}$ & 32,84 & 269,35 & 170,88 & 88,66 & $-3,08$ & 44,79 & 31,49 & 9,63 & 7,84 & 2,01 \\
\hline
\end{tabular}

Sumber: UN-Comtrade (2018)

Dari seluruh pasar ekspor utama komoditas lada Indonesia, pasar yang paling mendominasi volume ekspor komoditas ini adalah pasar Amerika
Serikat. Total volume ekspor lada ke pasar Amerika Serikat selama tahun 2002 hingga tahun 2016 adalah 244,31 ribu ton. Sedangkan total volume ekspor 
di pasar lainnya adalah Vietnam sebesar 111,24 ribu ton, Belanda sebanyak 32,49 ribu ton, Jerman sebanyak 31,29 ribu ton, Rusia sebanyak 10,82 ribu ton, Prancis sebanyak 9,71 ribu ton, Malaysia sebanyak 9,30 ribu ton, Australia sebanyak 5,76 ribu ton, Korea Selatan sebanyak 3,64 ribu ton, dan Belgia, sebanyak 3,44 ribu ton (Tabel 1).

Rata-rata pertumbuhan volume ekspor lada terbesar merupakan ratarata pertumbuhan di pasar Vietnam sebesar $269,35 \%$ per tahun. Tingginya pertumbuhan ekspor lada Indonesia di pasar Vietnam salah satunya disebabkan oleh harga lada Indonesia yang cenderung rendah di pasar Vietnam bila dibandingkan dengan harga di pasar lain.

Adapun pertumbuhan volume ekspor terendah adalah pertumbuhan volume ekspor di pasar Australia, sebesar $-3,08 \%$ per tahun. Negatifnya pertumbuhan volume ekspor lada Indonesia ke pasar Australia disebabkan oleh volume ekspor yang cenderung terus menurun selama beberapa tahun belakangan. Penurunan volume ekspor tersebut karena dalam beberapa tahun belakangan Australia lebih banyak meningkatkan impor ladanya dari negara lain, yaitu dari Singapura, India, Vietnam, Malaysia, Afrika Selatan, Spanyol dan China. Selain itu Australia juga memiliki eksportir baru, yaitu Belgia, Polandia, Swedia, Suriah, Bangladeh, Equador, Fiji, Mesir, Jamaika, Jepang, Serbia, Slovenia dan Switzerlad.

Nilai ekspor komoditas lada Indonesia di sepuluh pasar tujuan utama, rata-rata pertumbuhannya positif. Rata-rata pertumbuhan ekspor lada terendah $10,53 \%$ terjadi di pasar Australia. Sedangkan rata-rata pertumbuhan ekspor lada tertinggi terjadi di Vietnam sebesar 378,22\%.

Pasar Amerika Serikat
mendominasi nilai ekspor lada
Indonesia dengan total nilai ekspor USD 999,65 ribu selama 2002-2016 (Tabel 2). Sedangkan total nilai ekspor di pasar Vietnam adalah USD 665,08 ribu, di susul Jerman (USD 185,82 ribu), Belanda (USD 179,72 ribu), Prancis (USD 65.96 ribu), Malaysia (USD 61.10 ribu), Rusia (USD 37.21 ribu), Australia (USD 23.641 ribu) dan Belgia (USD 22.29 ribu). Total nilai terendah adalah ke pasar Korea Selatan USD 16.09 ribu. 
Tabel 2. Nilai Ekspor Lada Indonesia ke Sepuluh Pasar Utama (dalam Ribu USD)

\begin{tabular}{cccccccccccc}
\hline Tahun & Malaysia & Vietnam & Korsel & Rusia & Australia & Prancis & Belgia & Belanda & Jerman & AS \\
\hline 2002 & 533 & 51 & 297 & 136 & 572 & 642 & 43 & 4.396 & 2.485 & 26.137 \\
2003 & 167 & 2.024 & 237 & 1.689 & 513 & 623 & 95 & 4.849 & 4.072 & 27.238 \\
2004 & 87 & 866 & 104 & 1.076 & 669 & 150 & 459 & 2.859 & 3.949 & 17.863 \\
2005 & 115 & 390 & 197 & 1.320 & 1.114 & 169 & 582 & 3.918 & 3.069 & 18.213 \\
2006 & 864 & 2.865 & 43 & 605 & 872 & 1.074 & 453 & 3.802 & 5.345 & 28.090 \\
2007 & 2.327 & 6.979 & 1.140 & 1.362 & 1.021 & 1.237 & 948 & 11.450 & 10.468 & 54.510 \\
2008 & 1.991 & 15.506 & 1.422 & 1.640 & 2.129 & 4.146 & 1.335 & 11.701 & 9.742 & 82.710 \\
2009 & 2.192 & 13.667 & 1.404 & 2.787 & 1.688 & 2.075 & 710 & 6.978 & 8.204 & 63.385 \\
2010 & 4.949 & 54.737 & 2.244 & 7.015 & 4.003 & 3.612 & 1.027 & 12.264 & 11.683 & 94.939 \\
2011 & 6.674 & 31.931 & 2.099 & 1.129 & 2.573 & 4.346 & 841 & 10.741 & 10.745 & 84.329 \\
2012 & 7.923 & 105.307 & 1.848 & 10.561 & 3.277 & 4.216 & 1.718 & 16.741 & 17.824 & 156.769 \\
2013 & 6.372 & 80.241 & 984 & 3.585 & 1.786 & 7.718 & 4.050 & 22.862 & 17.969 & 105.799 \\
2014 & 6.876 & 48.165 & 561 & 600 & 1.751 & 7.152 & 4.325 & 16.037 & 25.693 & 56.299 \\
2015 & 9.873 & 179.912 & 806 & 1.584 & 1.553 & 10.100 & 5.051 & 23.814 & 32.562 & 104.756 \\
2016 & 10.158 & 122.435 & 2.705 & 2.118 & 119 & 18.698 & 653 & 27.305 & 22.011 & 78.609 \\
\hline Total Nilai & 61.101 & 665.076 & 16.091 & 37.207 & 23.640 & 65.958 & 22.290 & 179.717185 .820 & 999.646 \\
\hline $\begin{array}{c}\text { Rata-rata } \\
\text { Pertumbuhan } \\
\text { (\%) }\end{array}$ & 67,60 & 378,22 & 195,42 & 159,77 & 10,53 & 68,88 & 58,09 & 25,39 & 23,16 & 18,19 \\
\hline Sumber: UN-Comtade & & & & & & & & & & &
\end{tabular}

Sumber: UN-Comtrade (2018)

Berdasarkan data volume dan nilai ekspor lada Indonesia ke sepuluh pasar utama tersebut, terlihat adanya perbedaan fluktuasi dan pertumbuhan pada volume dan nilai ekspor. Adanya perbedaan ini disebabkan oleh perubahan harga ekspor lada dari tahun ke tahun di setiap negara. Perubahan harga ekspor lada setiap tahunnya menyebabkan laju pertumbuhan volume ekspor lebih lambat dibanding dengan laju pertumbuhan nilai ekspornya. Hal ini pulalah yang menjelaskan mengapa rata-rata pertumbuhan volume ekspor lada Indonesia di pasar Australia bernilai negatif, namun rata-rata pertumbuhan nilai ekspor di pasar Malaysia bernilai positif.

Harga ekspor lada diperoleh dari nilai ekspor lada di negara tujuan dibagi dengan volume ekspornya (Kementerian Pertanian RI, 2015). Harga lada di setiap pasar pada setiap tahunnya cukup bervariasi. Secara ratarata harga ekspor komoditas lada di setiap pasar bertumbuh. 
Tabel 3. Harga Ekspor Lada Indonesia

\begin{tabular}{|c|c|c|c|c|c|c|c|c|c|c|}
\hline \multirow{2}{*}{$\begin{array}{c}\text { Tahun } \\
2002\end{array}$} & \multirow{2}{*}{$\begin{array}{c}\text { Malaysia } \\
0,96\end{array}$} & \multirow{2}{*}{$\begin{array}{c}\text { Vietnam } \\
0,98\end{array}$} & \multirow{2}{*}{$\begin{array}{c}\text { Korsel } \\
1,46\end{array}$} & \multirow{2}{*}{$\begin{array}{c}\text { Rusia } \\
0,57\end{array}$} & \multirow{2}{*}{$\begin{array}{c}\text { Australia } \\
1,77\end{array}$} & \multirow{2}{*}{$\begin{array}{c}\text { Prancis } \\
1,82\end{array}$} & \multirow{2}{*}{$\frac{\text { Belgia }}{1,55}$} & \multicolumn{2}{|c|}{ Belanda Jerman } & \multirow{2}{*}{$\frac{\text { AS }}{1,60}$} \\
\hline & & & & & & & & \multicolumn{2}{|c|}{$1,85 \quad 1,93$} & \\
\hline 2003 & 1,34 & 1,32 & 2,09 & 1,32 & 1,70 & 1,39 & 1,36 & 1,56 & 2,10 & 1,54 \\
\hline 2004 & 1,62 & 2,29 & 0,97 & 1,25 & 1,48 & 1,30 & 2,19 & 1,90 & 2,08 & 1,52 \\
\hline 2005 & 1,29 & 1,18 & 0,84 & 1,21 & 1,62 & 1,65 & 2,09 & 2,01 & 1,95 & 1,38 \\
\hline 2006 & 2,13 & 2,37 & 2,10 & 1,69 & 2,38 & 2,96 & 3,00 & 2,37 & 2,59 & 1,84 \\
\hline 2007 & 3,77 & 3,16 & 2,61 & 2,99 & 3,73 & 4,83 & 3,71 & 4,11 & 4,20 & 3,20 \\
\hline 2008 & 4,56 & 3,64 & 3,52 & 3,00 & 4,25 & 4,26 & 4,55 & 4,44 & 4,17 & 3,26 \\
\hline 2009 & 3,57 & 2,68 & 2,92 & 2,56 & 3,08 & 4,21 & 3,50 & 3,92 & 3,92 & 2,56 \\
\hline 2010 & 3,31 & 3,90 & 4,44 & 3,58 & 4,30 & 4,33 & 4,13 & 4,79 & 5,22 & 3,78 \\
\hline 2011 & 6,93 & 6,71 & 7,31 & 5,50 & 6,32 & 7,20 & 6,22 & 7,53 & 8,14 & 5,51 \\
\hline 2012 & 8,51 & 6,11 & 6,98 & 6,36 & 8,33 & 7,65 & 7,66 & 8,49 & 7,87 & 6,84 \\
\hline 2013 & 9,09 & 6,68 & 8,05 & 6,39 & 8,18 & 7,87 & 8,85 & 8,55 & 8,38 & 7,22 \\
\hline 2014 & 10,76 & 7,87 & 14,40 & 8,00 & 8,84 & 9,64 & 10,29 & 11,28 & 10,44 & 9,16 \\
\hline 2015 & 13,04 & 7,93 & 13,21 & 8,99 & 10,93 & 11,29 & 12,34 & 12,57 & 11,36 & 10,36 \\
\hline 2016 & 11,16 & 6,33 & 7,57 & 8,22 & 6,45 & 9,36 & 11,16 & 9,72 & 9,59 & 9,20 \\
\hline $\begin{array}{c}\text { Harga } \\
\text { Rata-rata }\end{array}$ & 5,47 & 4,21 & 5,23 & 4,11 & 4,89 & 5,32 & 5,51 & 5,67 & 5,60 & 4,60 \\
\hline $\begin{array}{c}\text { Rata-rata } \\
\text { Pertumbuhan }\end{array}$ & $24,20 \%$ & $21,31 \%$ & 23,05 & 25,8 & $3,53 \%$ & 16,2 & 17,4 & 5,2 & 14,3 & $16,08 \%$ \\
\hline
\end{tabular}

Sumber: UN-Comtrade (2018)

Selama 2002-2016, rata-rata harga ekspor lada tertinggi sebesar 5,67 USD/kg di pasar Belanda, dan harga terendah sebesar USD 4,11/kg di pasar Rusia. Harga di berbagai pasar tujuan utama berada pada kisaran tersebut (Tabel 3).

Harga ekspor lada Indonesia di pasar Vietnam hanya sedikit lebih tinggi dibanding harga di Rusia yaitu USD 4,21/kg karena Vietnam bukanlah negara pengkonsumsi lada. Impor lada Vietnam dari Indonesia sebagian besar di ekspor kembali ke negara lain. Menurut Kementerian Pertanian RI (2015), Vietnam merupakan salah satu negara produsen sekaligus eksportir lada terbesar di pasar dunia. Hal inilah yang meyebabkan harga ekspor lada Indonesia di pasar Vietnam cenderung lebih murah.

Kinerja ekspor lada Indonesia selama ini ditopang oleh produksi dan luas lahannya. Berdasarkan data Kementerian Pertanian, produksi dan luas lahan lada Indonesia berfluktuasi. 
Tabel 4. Produksi dan Luas Lahan Lada Indonesia

\begin{tabular}{ccc}
\hline Tahun & $\begin{array}{c}\text { Produksi } \\
\text { (ton) }\end{array}$ & $\begin{array}{c}\text { Luas Lahan } \\
\text { (ha) }\end{array}$ \\
\hline 2010 & 83.662 & 179.318 \\
2011 & 87.089 & 177.490 \\
2012 & 87.841 & 177.787 \\
2013 & 91.037 & 171.920 \\
2014 & 87.448 & 152.751 \\
\hline
\end{tabular}

Sumber : Kementerian Pertanian RI (2017)

Produksi lada Indonesia terbesar selama periode 2010-2014 adalah sebesar 91.037 ton pada tahun 2013 Luas lahan lada terluas pada periode tersebut adalah seluas $179.318 \mathrm{~m}^{2}$ pada tahun 2010. Perkembangan produksi lada di tengah menyusutnya luas lahan lada Indonesia tentu menjadi penopang sekaligus modal bagi pengembangan ekspor lada Indonesia (Tabel 4).

Melihat kinerja ekspor lada Indonesia di pasar internasional, kinerja perdagangan lada dunia, serta produksi lada dalam negeri, maka dirasa perlu untuk mengkaji tentang pengembangan ekspor lada Indonesia. Berdasarkan uraian tersebut di atas, penelitian ini bertujuan untuk menganalisis daya saing komoditas lada sehingga ditemukan pasar ekspor yang optimis dan potensial untuk dikembangkan. Selain itu, penelitian ini juga bertujuan untuk menganalisis faktor-faktor yang memengaruhi permintaan ekspor komoditas lada Indonesia di pasar internasional.

\section{METODE}

Penelitian ini berkontribusi dengan melengkapi hasil penelitian yang sudah ada. Kebaruannya ada pada kebaruan data terkini, serta ragam pasar yang diteliti yang merupakan sepuluh pasar terbesar Indonesia.

Penelitian ini menggunakan data sekunder yang bersifat kuantitatif. Jenis data yang digunakan merupakan data panel yang terdiri dari data time series dan data cross section. Data time series terangkum dalam bentuk tahunan, yaitu data tahun 2002-2016. Sedangkan data cross section merupakan data sepuluh pasar ekspor utama lada.

Data yang digunakan adalah data nilai ekspor, volume ekspor, Produk Domestik Bruto (PDB) per kapita, populasi, tarif dan jarak. Data tersebut diperoleh dari United Nations of Comodity Trade Database (UNComtrade), World Development Indicators (WDI) World Bank, World Trade Organization (WTO) dan CEPII. Kode HS komoditas yang diteliti adalah 0904 (lada).

Dalam melakukan analisis pengembangan pasar ekspor lada, penelitian ini menggunakan metode 
Revealed Comparative Advantage (RCA), Export Product Dynamics (EPD), X-Model dan Graviy Model. Metode RCA, EPD dan X-Model digunakan untuk menganalisis daya saing, sehingga ditemukan pasar ekspor yang optimis dan potensial. Sedangkan metode Gravity Model digunakan untuk menganalisis faktor apa saja yang memengaruhi permintaan ekspor komoditas lada.

\section{Revealed Comparative Advantage} (RCA)

RCA merupakan salah satu metode yang digunakan untuk mengukur daya saing atau keunggulan komparatif di suatu wilayah. Adapun rumus dari RCA adalah sebagai berikut:

$R C A=\frac{\left(X_{a j}\right) /\left(X_{t j}\right)}{\left(W_{a j}\right) /\left(W_{t j}\right)}$

dimana :

$X_{\text {aj }}$ :Nilai ekspor lada Indonesia ke negara j

$W_{\text {aj }}:$ Nilai ekspor lada dunia ke negara $j$

$X_{\mathrm{tj}}$ :Nilai total ekspor Indonesia ke negara $\mathrm{j}$

$\mathrm{W}_{\mathrm{tj}}$ : Nilai total ekspor dunia ke negara $\mathrm{j}$ Hasil perhitungan nilai RCA menunjukkan dua kemungkinan, apabila nilai RCA lebih dari satu maka lada di negara tersebut memiliki keunggulan komparatif sehingga memiliki nilai daya saing kuat. Apabila nilai RCA kurang dari satu maka dianggap memiliki daya saing lemah.

\section{Export Product Dynamics (EPD)}

EPD merupakan metode yang digunakan untuk mengukur posisi pasar dari produk suatu negara. Adapun rumus dari EPD adalah sebagai berikut: Sumbu $\mathrm{x}$ : Pertumbuhan pangsa pasar ekspor

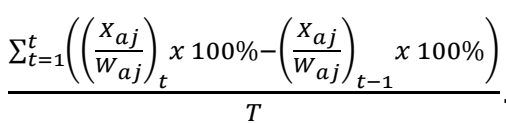

Sumbu y: Pertumbuhan pangsa pasar produk

$\frac{\sum_{t=1}^{t}\left(\left(\frac{x_{t j}}{w_{t j}}\right)_{t} \times 100 \%-\left(\frac{x_{t j}}{w_{t j}}\right)_{t-1} \times 100 \%\right)}{T}$

dimana:

$\mathrm{X}_{\mathrm{aj}}$ :Nilai ekspor lada Indonesia ke negara j

$W_{\text {aj }}$ :Nilai ekspor lada dunia ke negara $\mathrm{j}$

$\mathrm{X}_{\mathrm{tj}}$ : Nilai total ekspor lada Indonesia ke negara j

$\mathrm{W}_{\mathrm{tj}}$ : Nilai total ekspor dunia ke negara $\mathrm{j}$ $\mathrm{T}$ : Jumlah tahun

Hasil analisis daya saing lada akan berada di salah satu dari keempat kuadran. Posisi komoditas lada tergantung pada daya tarik pasar dan kekuatan bisnis komoditas tersebut. 
Dengan matriks daya saing menggunakan EPD tersebut, dapat dilihat posisi daya saing masing-masing komoditas.

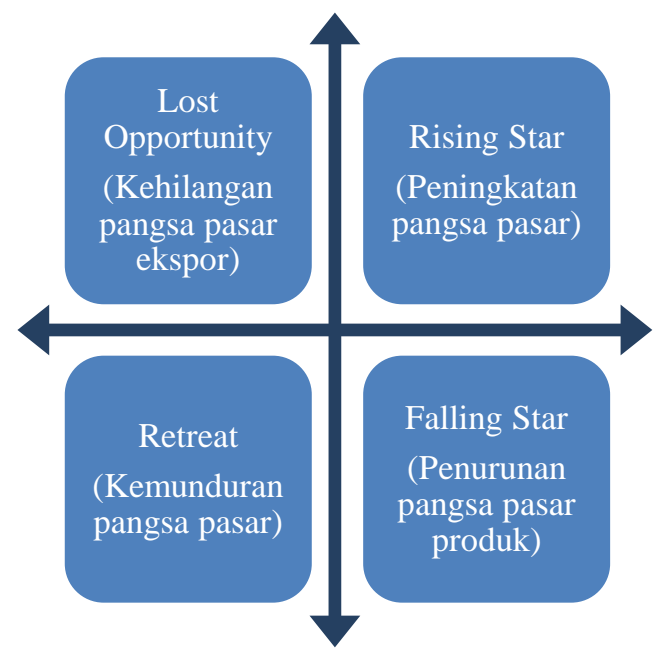

Gambar 2. Posisi Daya Saing Produk dengan Metode EPD

Sumber: Estherhuizen (2006)

\section{X-Model Potential Export Products}

Metode ini menggabungkan hasil analisis metode RCA dengan hasil analisis metode EPD, dengan menggunakan metode ini hasil analisis daya saing yang diteliti menjadi lebih komprehensif karena melihat daya saing komoditas Lada Indonesia dari dua sisi sekaligus, yaitu dari sisi RCA dan juga EPD. Metode ini digunakan untuk melakukan klusterisasi potensi produk di wilayah tertentu. Klusterisasi ini dilakukan untuk memfokuskan pasar perdagangan.

\begin{tabular}{|c|c|c|}
\hline & \multicolumn{2}{|c|}{ Potential Export Product } \\
\hline RCA & EPD & X-Model \\
\hline \multirow{4}{*}{$>1$} & $\begin{array}{l}\text { Rising Star } \\
\text { (Peningkatan } \\
\text { pangsa pasar) }\end{array}$ & Pasar Optimis \\
\hline & $\begin{array}{l}\text { Lost opprtunity } \\
\text { (Kehilangan pangsa } \\
\text { pasar ekspor) }\end{array}$ & Pasar Potensial \\
\hline & $\begin{array}{l}\text { Falling Star } \\
\text { (Penurunan pangsa } \\
\text { pasar produk) }\end{array}$ & Pasar Potensial \\
\hline & $\begin{array}{l}\text { Retreat } \\
\text { (Kemunduran } \\
\text { pangsa pasar) }\end{array}$ & Kurang Potensial \\
\hline \multirow{4}{*}{$<1$} & $\begin{array}{l}\text { Rising Star } \\
\text { (Peningkatan } \\
\text { pangsa pasar) }\end{array}$ & Pasar Potensial \\
\hline & $\begin{array}{l}\text { Lost opportunity } \\
\text { (Kehilangan pangsa } \\
\text { pasar ekspor) }\end{array}$ & Kurang Potensial \\
\hline & $\begin{array}{l}\text { Falling Star } \\
\text { (Penurunan pangsa } \\
\text { pasar produk) }\end{array}$ & Kurang Potensial \\
\hline & $\begin{array}{l}\text { Retreat } \\
\text { (Kemunduran } \\
\text { pangsa pasar) }\end{array}$ & Tidak Potensial \\
\hline
\end{tabular}

Sumber: Kementerian Perdagangan (2013)

\section{Gravity Model}

Gravity model digunakan untuk menganalisis faktor-faktor yang memengaruhi ekspor komoditas lada Indonesia ke negara tujuan. Penelitian ini menggunakan data cross section yang terdiri dari sepuluh negara tujuan utama ekspor komoditas lada dan data time series selama 15 tahun. Adapun model yang digunakan adalah:

$$
\begin{aligned}
& \ln X_{i j t}=\beta_{0}+\beta_{1} \ln P D B C_{j t}+\beta_{2} \ln P P_{j t}+ \\
& \beta_{3} \operatorname{lnH} E_{i j t}+\beta_{4} \mid n J E_{i j t}+\beta_{5} \operatorname{lnTRF} F_{j t}+ \\
& \text { Uijt. }
\end{aligned}
$$


dimana :

$\mathrm{X}_{\mathrm{ijt}} \quad$ : Volume ekspor $(\mathrm{kg})$

$\mathrm{PDBC}_{\mathrm{jt}}$ : PDB perkapita (USD/Jiwa)

POP $_{\text {jt }}$ : Populasi (Jiwa)

$\mathrm{HE}_{\mathrm{ijt}}$ : Harga ekspor (USD/Kg)

$J_{\mathrm{ijt}} \quad$ : Jarak ekonomi (Km)

TRF $_{\mathrm{jt}}$ : Tarif impor (\%)

Ln : Logaritma natural

Uijt : error term

Adapun rumus untuk jarak ekonomi menurut Inayah et.al (2015) dan Kementerian Perdagangan RI (2014) adalah :

$\mathrm{JE}_{\mathrm{ij}}=\mathrm{DIS}_{\mathrm{ij}} \times \frac{\mathrm{PDB}_{\mathrm{j}}}{\sum \mathrm{PDB}_{j}}$

dimana :

$\mathrm{JE}_{\mathrm{ij}} \quad$ : Jarak ekonomi $(\mathrm{km})$

DIS $_{\mathrm{ij}}$ : Jarak ibu kota negara $(\mathrm{km})$

PDB $_{j}$ : PDB negara j (USD)

¿PDBj: Total PDB negara j (USD)

Jarak ekonomi merupakan jarak geografis antar ibukota negara asal dan negara tujuan dikalikan dengan share PDB suatu negara terhadap total PDB negara yang diteliti. Penggunaan jarak ekonomi dijadikan sebagai indikator dari biaya transportasi dalam melakukan perdagangan. Biaya transportasi adalah salah satu faktor penghambat perdagangan internasional.
Kementerian Perdagangan RI (2014), jarak ekonomi dapat berpengaruh positif maupun negatif. Jarak ekonomi dapat berpengaruh positif bila faktor PDB menjadi faktor yang lebih dominan dibandingkan dengan jarak geografis. Faktor lain yang menyebabkan jarak ekonomi dapat berpengaruh positif terhadap ekspor adalah adanya komisi perdagangan dari suatu transaksi. Komisi transaksi yang diberikan kepada perantara (broker) akan memengaruhi transaksi perdagangan internasional. Sedangkan apabila jarak berpengaruh negatif maka faktor jarak geografis menjadi faktor yang lebih dominan dibandingkan dengan PDB dalam memengaruhi perdagangan. Hal ini disebabkan jarak dapat meningkatkan biaya transaksi pertukaran barang dan jasa internasional.

Gravity model dalam penelitian ini menggunakan panel data karena dianggap relevan dengan tujuan dan dapat memberikan informasi tentang faktor yang memengaruhi nilai ekspor Lada. Menurut Juanda (2012), terdapat tiga macam pendekatan dalam panel data, yaitu Common-Constant (Pooled 
Ordinary Least Square/PLS), Model Efek Tetap (Fixed Effect), dan Model Efek Acak (Random Effect).

Berikut adalah langkah pemilihan model serta uji kesesuaian model yang akan dilakukan dalam penelitian ini. Pemilihan model terbaik dalam analisis data panel dilakukan dengan beberapa pengujian, diantaranya:

1. Uji Chow

Uji Chow merupakan uji yang bertujuan untuk memilih FEM atau PLS. Hipotesis uji ini adalah:

$\mathrm{H}_{0}$ : Pooled Least Square (PLS)

$\mathrm{H}_{1}$ : Fixed Effect Model (FEM)

Jika nilai F-Stat hasil pengujian lebih besar dari F-tabel, maka cukup bukti untuk melakukan penolakan terhadap $\mathrm{H}_{0}$, artinya model yang dipilih adalah model fixed effect.

2. Uji Hausman

Uji Hausman merupakan uji yang bertujuan untuk memilih antara model FEM dan REM. Hipotesis uji ini adalah:

$\mathrm{H}_{0}:$ Random Effect Model (REM)

$\mathrm{H}_{1}$ : Fixed Effect Model (FEM)

Jika nilai uji Hausman berdasarkan hasil pengujian lebih besar dari chi square, maka cukup bukti untuk menolak $\mathrm{H}_{0}$, artinya model yang dipilih adalah fixed effect model.

\section{HASIL DAN PEMBAHASAN}

\section{Analisis Daya Saing Lada Indonesia}

Analisis internal dilakukan untuk mengidentifikasi aspek kekuatan dan aspek kelemahan suatu komoditas. Metode RCA merupakan metode yang dapat digunakan untuk mengukur keunggulan komparatif komoditas suatu negara di pasar dunia. Apabila nilai RCA lebih dari satu, maka ini berarti bahwa komoditas tersebut memiliki daya saing yang kuat di pasar dunia. Semakin tinggi nilai RCA, maka semakin besar pula daya saing komoditas negara tersebut di pasar dunia (Hasibuan et.al 2012). Namun apabila nilai RCA lebih kecil dari satu, maka berarti komoditas tersebut berdaya saing lemah di pasar dunia.

Berdasarkan hasil analisis dengan menggunakan metode RCA (Tabel 6), selama periode 2002-2016, daya saing komoditas lada Indonesia di setiap pasar memiliki keunggulan komparatif yang cukup bervariasi. Komoditas lada memiliki nilai daya saing yang berbedabeda di setiap pasar pada setiap tahunnya. Namun secara keseluruhan komoditas lada Indonesia di sepuluh pasar utama yang diteliti memiliki keunggulan komparatif dan berdaya saing kuat, kecuali di pasar Malaysia. 
Tabel 6. Nilai RCA Lada Indonesia di 10 Pasar Tujuan Utama

\begin{tabular}{cccccccccccc}
\hline \multirow{2}{*}{ Tahun } & \multicolumn{1}{c}{ Negara } \\
\cline { 2 - 12 } & Malaysia & Vietnam & Korsel & Rusia & Australia & Prancis & Belgia & Belanda & Jerman & AS \\
\hline 2002 & 0,53 & 5,43 & 0,58 & 17,01 & 2,22 & 9,55 & 0,66 & 11,45 & 11,73 & 17,84 \\
2003 & 0,19 & 34,08 & 0,39 & 152,75 & 2,45 & 9,48 & 1,35 & 14,98 & 18,02 & 19,73 \\
2004 & 0,05 & 27,26 & 0,13 & 76,08 & 3,32 & 3,11 & 7,49 & 10,03 & 18,14 & 12,21 \\
2005 & 0,07 & 36,22 & 0,29 & 63,96 & 5,18 & 3,87 & 9,45 & 12,88 & 13,34 & 11,72 \\
2006 & 0,32 & 27,26 & 0,06 & 30,52 & 3,50 & 22,11 & 6,04 & 11,40 & 21,64 & 15,49 \\
2007 & 0,50 & 25,15 & 1,59 & 67,96 & 3,08 & 18,88 & 8,94 & 24,80 & 27,63 & 23,53 \\
2008 & 0,52 & 25,37 & 1,92 & 47,66 & 5,33 & 49,56 & 13,88 & 20,42 & 25,94 & 29,55 \\
2009 & 0,36 & 26,75 & 1,95 & 49,64 & 4,36 & 24,78 & 9,24 & 13,67 & 21,87 & 23,00 \\
2010 & 0,59 & 34,45 & 1,67 & 65,11 & 8,64 & 32,16 & 12,40 & 17,51 & 22,69 & 26,98 \\
2011 & 0,72 & 25,18 & 0,86 & 9,83 & 3,78 & 29,21 & 7,56 & 7,91 & 18,63 & 17,00 \\
2012 & 1,09 & 41,01 & 0,86 & 84,98 & 4,61 & 29,40 & 16,44 & 13,99 & 26,05 & 32,53 \\
2013 & 1,14 & 44,22 & 0,97 & 29,17 & 2,87 & 52,57 & 42,83 & 21,41 & 23,92 & 19,80 \\
2014 & 1,28 & 40,75 & 0,51 & 4,20 & 1,84 & 42,42 & 43,36 & 14,48 & 36,63 & 9,70 \\
2015 & 2,01 & 42,63 & 0,67 & 8,46 & 1,84 & 46,30 & 48,51 & 22,04 & 36,60 & 14,02 \\
2016 & 1,73 & 40,79 & 2,67 & 6,83 & 3,32 & 89,77 & 18,83 & 28,72 & 25,88 & 11,56 \\
\hline Rata-rata & 0,74 & 31,77 & 1,01 & 47,61 & 3,76 & 30,88 & 16,47 & 16,38 & 23,25 & 18,98 \\
\hline & & & & & & & & & & \\
\hline
\end{tabular}

Posisi daya saing dengan nilai rata-rata $\mathrm{RCA}$ tertinggi berada di pasar Rusia dengan rata-rata nilai RCA sebesar 47,61. Kemudian secara berurutan disusul Vietnam, Prancis, Jerman, Amerika Serikat, Belgia, Belanda, Australia, Korea Selatan dan Malaysia (Tabel 6). Hasil analisis ratarata RCA menunjukkan bahwa komoditas lada memiliki keunggulan komparatif dan berdaya saing kuat di setiap tahun pada pasar Rusia, Vietnam, Prancis, Jerman, Amerika Serikat, Belanda dan Australia.
Di pasar Malaysia, komoditas lada Indonesia pada tahun 2002 hingga tahun 2011 berdaya saing lemah, hal inilah yang menyebabkan rata-rata RCA komoditas lada Indonesia selama 20022016 berdaya saing lemah. Namun demikian, bila nilai daya saing komoditas lada di pasar Malaysia dilihat lebih spesifik per tahun, daya saing komoditas ini terus mengalami peningkatan. Sejak tahun 2012 hingga 2016 nilai RCA di pasar Malaysia selalu lebih dari satu. Sehingga meskipun secara rata-rata nilai daya saing 
komoditas lada di pasar Malaysia selama 2002-2016 berdaya saing lemah, namun bila dilihat lebih spesifik per tahun daya saing komoditas ini terus mengalami peningkatan dan berdaya saing kuat selama empat tahun terakhir.

Selanjutnya dilakukan analisis EPD untuk mengukur posisi pasar dari komoditas suatu negara untuk tujuan pasar tertentu. Metode ini menunjukkan dinamis atau tidaknya kinerja masing- masing komoditas. Analisis EPD dapat menunjukkan posisi daya saing suatu komoditas yang terbagi menjadi empat posisi yaitu rising star (peningkatan pangsa pasar), falling star (penurunan pangsa pasar produk), lost opportunity (kehilangan pangsa pasar ekspor), dan retreat (Kemunduran pangsa pasar). Hasil analisis EPD menunjukkan posisi pasar komoditas lada di masing-masing pasar yang diteliti cukup bervariasi.

Tabel 7. Hasil Analisis EPD Lada Indonesia, 2002-2016

\begin{tabular}{lccc}
\hline Negara & $\begin{array}{c}\text { Pertumbuhan } \\
\text { Pangsa Pasar } \\
\text { Ekspor (\%) }\end{array}$ & $\begin{array}{c}\text { Pertumbuhan } \\
\text { Pangsa Pasar } \\
\text { Produk (\%) }\end{array}$ & Posisi Pasar \\
\hline Malaysia & 0,312 & 0,121 & Peningkatan pangsa pasar \\
Vietnam & 4,248 & $-0,016$ & Penurunan pangsa pasar produk \\
Korea Selatan & 0,289 & $-0,063$ & Penurunan pangsa pasar produk \\
Rusia & $-0,513$ & 0,036 & Kehilangan pangsa pasar ekspor \\
Australia & $-0,313$ & $-0,078$ & Kemunduran pangsa pasar \\
Prancis & 0,576 & $-0,005$ & Penurunan pangsa pasar produk \\
Belgia & 0,263 & $-0,008$ & Penurunan pangsa pasar produk \\
Belanda & 0,361 & 0,003 & Peningkatan pangsa pasar \\
Jerman & 0,224 & $-0,001$ & Penurunan pangsa pasar produk \\
Amerika Serikat & $-0,222$ & 0,003 & Kehilangan pangsa pasar ekspor \\
\hline
\end{tabular}

Ekspor komoditas lada Indonesia berada pada posisi rising star (peningkatan pangsa pasar) di pasar Malaysia dan Belanda. Sedangkan di pasar Rusia dan Amerika Serikat, ekspor lada Indonesia berada pada posisi lost opportunity (kehilangan pangsa pasar ekspor). Ini berarti bahwa ekspor lada Indonesia ke pasar-pasar tersebut mengalami kehilangan kesempatan untuk meningkatkan pangsa pasar ekspor. Di pasar Vietnam, Korea Selatan, Prancis, Belgia dan Jerman, ekspor lada Indonesia berada 
pada posisi falling star (penurunan pangsa pasar produk). Ini berarti bahwa Indonesia kehilangan kesempatan untuk meningkatkan pangsa pasar produknya di pasar-pasar tersebut. Sedangkan di pasar Australia, ekspor lada Indonesia berada pada posisi retreat (kemunduran pangsa pasar). Ini berarti bahwa komoditas lada Indonesia kehilangan kesempatan untuk meningkatkan pangsa pasar ekspor sekaligus pangsa pasar produk di pasar Australia.

Pada tahun 2004 dan 2014, produksi lada Indonesia mengalami penurunan. Penurunan tersebut menjadi salah satu penyebab hilangnya pangsa pasar ekspor lada Indonesia di pasar Rusia, Australia dan Amerika Serikat pada tahun 2004 dan 2014. Pada tahun 2004 produksi lada Indonesia turun sebesar 15,13\% dan pada tahun 2014 produksi lada Indonesia turun sebesar $3,94 \%$. Sedangkan faktor lain yang juga memengaruhi hilangnya pangsa pasar ekspor lada Indonesia pada tahun tersebut juga di tahun-tahun lainnya adalah karena adanya perubahan komposisi volume impor lada dari setiap eksportir.

Di pasar Rusia, hilangnya pangsa pasar ekspor komoditas lada Indonesia disebabkan oleh pertumbuhan pangsa pasar ekspor pada tahun 2002, 2004, 2006, 2008, 2011, 2013 dan 2014 bernilai negatif. Pada tahun 2002 perubahan komposisi volume impor lada yang terjadi di pasar Rusia adalah karena pada tahun tersebut komposisi volume impor lada diantaranya banyak beralih ke Malaysia, India dan Vietnam dibanding tahun sebelumnya. Pada tahun 2008 banyak beralih ke China, Vietnam dan India. Pada tahun 2011 beralih ke Vietnam, India, Peru, Austria, Polandia, China dan Meksiko. Dan pada tahun 2013 beralih Vietnam, Austria, Polandia, China dan Singapura.

Di pasar Australia, hilangnya pangsa pasar ekspor komoditas lada disebabkan oleh pertumbuhan pangsa pasar ekspor pada tahun 2002, 2003, 2006, 2007, 2009, 2011, 2013, 2014 dan 2015 bernilai negatif. Pada 2002 perubahan komposisi volume impor lada yang terjadi di pasar Australia adalah karena pada tahun tersebut Australia lebih banyak mengimpor lada diantaranya dari Singapura, India dan Vietnam dibanding tahun sebelumnya. Pada tahun 2003 Australia meningkatkan impor lada diantaranya dari Vietnam, Malaysia, dan Afrika Selatan. Pada tahun 2009 diantaranya banyak beralih ke India dan Vietnam. 
Selain itu pada tahun 2009 Australia mengimpor lada dari beberapa eksportir baru, diantaranya Belgia, Polandia, Swedia dan Suriah. Tahun 2011 Australia meningkatkan impor lada diantaranya dari Spanyol, Vietnam dan India. Pada tahun 2013 diantaranya banyak beralih ke Spanyol, Afrika Selatan dan Vietnam. Pada tahun 2014 lebih banyak mengimpor lada diantaranya dari China, Spanyol, Vietnam dan India. Pada tahun 2015 meningkatkan impor lada diantaranya dari Spanyol Singapura, serta melakukan impor dari eksportir baru, yaitu diantaranya dari Bangladeh, Equador, Fiji, Mesir, Jamaika, Jepang, Serbia, Slovenia dan Switzerlad.

Di pasar Amerika Serikat, hilangnya pangsa pasar ekspor komoditas lada disebabkan oleh pertumbuhan pangsa pasar ekspor pada tahun 2002, 2003, 2004, 2005, 2009, 2011, 2013, 2014 dan 2016 bernilai negatif. Pada tahun 2002 perubahan komposisi volume impor lada Indonesia yang terjadi di pasar Amerika Serikat adalah karena pada tahun tersebut Amerika Serikat lebih banyak meningkatkan komposisi impor lada diantaranya dari India dan Brazil dibanding dari Indonesia. Selain itu pada tahun 2002 Amerika Serikat juga melakukan impor dari eksportir baru, yaitu diantaranya dari Denmark, Austria, Iran, Kenya, Malawi, Slovakia, Zambia dan Zimbabwe. Tahun 2003 Amerika Serikat meningkatkan impor lada diantaranya dari Meksiko, China, Peru dan Jerman. Tahun 2005 meningkat diantaranya dari Peru. Tahun 2009 peningkatan impor lada terjadi pada impor dari Peru, China, Vietnam dan Brazil. Tahun 2011 diantaranya dari Peru, Vietnam, India china brazil. Pada tahun 2013 lebih banyak mengimpor lada diantaranya dari Peru, Meksiko dan Brazil. Tahun 2015 diantaranya dari India, Meksiko, China, Bangladeh, Equador, Fiji, Mesir, Jamaika, Jepang, Serbia, Slovenia dan Switzerlad.

Di pasar Vietnam, Korea Selatan, Australia, Prancis, Belgia dan Jerman, hilangnya pangsa pasar produk di pasar tersebut disebabkan karena perbandingan total ekspor Indonesia ke negara tersebut dengan total ekspor dunia ke negara tersebut cenderung mengalami penurunan dari tahun ke tahun. Hal ini menyebabkan Indonesia kehilangan pangsa pasar produk di pasar-pasar tersebut.

Berdasarkan hasil analisis RCA dan EPD, dapat dilakukan klusterisasi 
potensi pengembangan pasar analisis RCA dan posisi pasar yang komoditas lada di 10 pasar utama. diperoleh dari hasil analisis EPD. Metode yang digunakan untuk Dengan menggunakan metode ini, hasil melakukan klusterisasi adalah metode analisis daya saing yang diteliti menjadi $x$-model potential export products, yaitu lebih komprehensif karena melihat daya metode yang mempertimbangkan nilai daya saing yang diperoleh dari hasil saing komoditas lada Indonesia dari dua sisi sekaligus, yaitu sisi RCA dan EPD.

\section{Tabel 8. Hasil Analisis X-Model Lada Indonesia Tahun 2002-2016}

\begin{tabular}{lcrc}
\hline \multicolumn{1}{c}{ Negara } & RCA & EPD & Potensi Pengembangan Pasar \\
\hline Malaysia & 0,74 & Peningkatan pangsa pasar & Potensial \\
Vietnam & 31,77 & Penurunan pangsa pasar produk & Potensial \\
Korsel & 1,01 & Penurunan pangsa pasar produk & Potensial \\
Rusia & 47,61 & Kehilangan pangsa pasar ekspor & Potensial \\
Austsralia & 3,76 & Kemunduran pangsa pasar & Kurang Potenisial \\
Perancis & 30,88 & Penurunan pangsa pasar produk & Potensial \\
Belgia & 16,47 & Penurunan pangsa pasar produk & Potensial \\
Belanda & 16,38 & Peningkatan pangsa pasar & Optimis \\
Jerman & 23,25 & Penurunan pangsa pasar produk & Potensial \\
Amerika Serikat & 18,98 & Kemunduran pangsa pasar & Potensial \\
\hline
\end{tabular}

Berdasarkan Tabel 8 ekspor komoditas lada memiliki potensi pengembangan pasar optimis di pasar Belanda. Di pasar tersebut komoditas lada Indonesia memiliki daya saing yang kuat sekaligus berada pada posisi rising star (peningkatan pangsa pasar). Sedangkan di pasar Malaysia, Vietnam, Korea Selatan, Rusia, Prancis, Belgia, Jerman, dan Amerika Serikat ekspor komoditas lada memiliki potensi pengembangan pasar yang potensial. Dan di pasar Australia ekspor komoditas lada memiliki potensi pengembangan pasar yang kurang potensial.

Lada Indonesia di pasar Malaysia memiliki potensi pengembangan pasar yang potensial karena meskipun nilai RCA komoditas ini kurang dari satu, namun komoditas ini berada pada posisi rising star (peningkatan pangsa pasar). Sedangkan lada Indonesia di pasar Vietnam, Korea Selatan, Rusia, Perancis, Belgia, Jerman, dan Amerika Serikat memiliki potensi pengembangan pasar yang potensial karena komoditas 
ini memiliki daya saing yang kuat dengan RCA lebih dari satu, meskipun komoditas ini berada pada posisi lost opportunity (kehilangan pangsa pasar ekspor), atau falling star (penurunan pangsa pasar produk).

\section{Analisis Faktor-faktor yang Memengaruhi Permintaan Lada Indonesia}

Dalam menentukan model yang terbaik, maka dilakukan uji Chow dan uji Hausman. Berdasarkan hasil uji Chow menunjukkan bahwa probabilitas lebih kecil dari taraf nyata $5 \%(0,00<0,05)$, berarti cukup bukti untuk tolak $\mathrm{H}_{0}$, artinya pendekatan model yang dipilih adalah pendekatan model fixed effect. Selanjutnya dilakukan uji Hausman. Hasil uji Hausman menunjukkan bahwa nilai probabilitasnya lebih kecil dari taraf nyata $5 \%(0,01<0,05)$, berarti cukup bukti untuk tolak $\mathrm{H}_{0}$, artinya pendekatan model yang dipilih adalah pendekatan model fixed effect. Berdasarkan hasil pengujian, pendekatan model terbaik yang dipilih adalah pendekatan model fixed effect.

Pengolahan dengan pendekatan model fixed effect ini dilakukan dengan pilihan kriteria pembobotan, yaitu dengan memberikan pembobotan SUR cross-section weighted sehingga parameter penduga dapat signifikan pada taraf nyata tertentu. Metode ini adalah metode yang mampu mengoreksi heteroskedastisitas serta autokorelasi antar unit cross section (Andari, 2017).

\section{Tabel 9. Hasil Estimasi Faktor yang} Memengaruhi Ekspor Lada

\begin{tabular}{lll}
\hline Variabel & Koefisien & Probability \\
\hline C & $-52,25095$ & $0,0245^{*}$ \\
LNPDBC & 1,579517 & $0,0005^{\star}$ \\
LNPOP & 3,475413 & $0,0057^{\star}$ \\
LNHE & $-0,250673$ & $0,0376^{\star *}$ \\
LNJE & $-1,752590$ & $0,0001^{*}$ \\
TRF & $-0,230570$ & $0,0000^{*}$ \\
\hline R-squared & \multicolumn{2}{c}{0,976571} \\
Adjusted R- & \multicolumn{2}{c}{0,974141} \\
squared
\end{tabular}

Keterangan: * ${ }^{* *}$ Signifikan pada taraf nyata $1 \%, 5 \%$

Berdasarkan hasil estimasi pada Tabel 9, nilai koefisien determinasi $\left(R^{2}\right)$ untuk komoditas HS 0904 adalah sebesar 0,976571. Artinya sebesar $97,66 \%$ keragaman faktor-faktor yang memengaruhi nilai ekspor komoditas tersebut di 10 pasar tujuan utama dapat dijelaskan oleh variabel-variabel bebasnya, sedangkan 2,34\% sisanya dijelaskan oleh faktor di luar model.

Adapun faktor-faktor yang signifikan memengaruhi permintaan ekspor lada Indonesia adalah PDB per 
kapita, populasi, harga ekspor, jarak ekonomi dan tarif. Variabel PDB per kapita, populasi, jarak ekonomi dan tarif signifikan pada taraf nyata $1 \%$. Sedangkan variabel harga ekspor memiliki pengaruh yang signifikan pada taraf nyata $5 \%$.

Variabel PDB per kapita negara tujuan berpengaruh positif terhadap ekspor komoditas lada Indonesia, dimana setiap kenaikan PDB per kapita negara tujuan sebesar $1 \%$ maka volume ekspor lada akan meningkat sebesar $1,58 \%$, begitu pula sebaliknya (ceteris paribus). PDB per kapita negara tujuan mencerminkan daya beli masyarakat, ini berarti bahwa peningkatan daya beli masyarakat di negara tujuan akan meningkatkan volume ekspor lada Indonesia. Hal ini sesuai dengan teori permintaan yang mengatakan bahwa peningkatan pendapatan per kapita akan meningkatkan permintaan terhadap komoditas yang diperdagangkan (Pindyck \& Rubenfield, 2009). Temuan ini serupa dengan penelitian Ningsih (2013).

Variabel populasi negara tujuan berpengaruh positif terhadap ekspor komoditas lada Indonesia, dimana setiap kenaikan populasi negara tujuan sebesar $1 \%$ maka volume ekspor lada akan meningkat sebesar 3,47\%. Populasi negara tujuan mencerminkan besarnya pasar di negara tujuan, semakin besar pasar maka akan semakin besar pula volume ekspor lada Indonesia ke negara tujuan. Hal ini sesuai dengan penelitian Irgandhini \& Firdaus (2014). dan penelitian Jordan (2014). Penelitian tersebut menemukan bahwa populasi negara tujuan berpengaruh positif dan signifikan terhadap ekspor.

Variabel harga ekspor memiliki pengaruh yang negatif, dimana setiap kenaikan harga sebesar $1 \%$ maka volume ekspor akan menurun sebesar 0,25\%. Meningkatnya harga ekspor membuat biaya yang dikeluarkan oleh negara tujuan menjadi lebih tinggi, hal ini akan menurunkan permintaan ekspor Indonesia sehingga volume ekspor lada akan menurun. Hal ini sesuai dengan hasil analisis Maulana \& Kartiasih, 2017, ditemukan bahwa harga ekspor berpengaruh signifikan dan negatif terhadap volume ekspor Indonesia. Namun demikian koefisien variabel harga menunjukkan bahwa lada adalah barang yang inelastis, sehingga kebijakan menurunkan harga justru dapat mengurangi penerimaan ekspor (Nicholson, 2002). Karenanya untuk 
dapat meningkatkan penerimaan ekspor komoditas lada, harga ekspor lada perlu dijaga stabilitasnya.

Variabel jarak ekonomi antara Indonesia dengan negara tujuan memiliki pengaruh yang negatif, dimana setiap kenaikan 1\% jarak ekonomi akan menurunkan volume ekspor lada sebesar $1,75 \%$. Variabel jarak ekonomi mencerminkan biaya ekspor, sehingga meningkatnya jarak ekonomi mengakibatkan biaya yang dikeluarkan negara tujuan menjadi lebih tinggi, karenanya peningkatan jarak ekonomi akan menurunkan permintaan ekspor lada. Hal ini sesuai dengan hasil penelitian Suryana et.al (2014) dan Inayah et.al (2015). Ditemukan hal yang sama, yaitu jarak ekonomi antara negara asal dengan negara tujuan berpengaruh negatif terhadap ekspor.

Variabel tarif memiliki pengaruh yang negatif terhadap volume ekspor lada Indonesia, dimana setiap kenaikan tarif sebesar 1\% maka volume ekspor akan menurun sebesar 0,23\%. Meningkatnya tarif ekspor di negara tujuan mengakibatkan penurunan volume ekspor lada Indonesia ke negara tujuan. Berdasarkan penelitian yang dilakukan oleh Kis-Katos \& Sparrow (2015), ditemukan hasil yang serupa, yaitu keberadaan tarif di negara tujuan memberikan pengaruh yang negatif terhadap ekspor. Sehingga apabila tarif naik maka nilai ekspor akan turun, namun bila tarif mengalami penurunanan atau penghapusan maka nilai ekspor akan meningkat. Hal ini sesuai dengan penelitian yang dilakukan oleh Kis-Katos \& Sparrow (2015), yaitu keberadaan tarif di negara tujuan memberikan pengaruh yang negatif terhadap ekspor.

\section{KESIMPULAN DAN REKOMENDASI KEBIJAKAN}

Lada sebagai salah satu produk Indonesia merupakan komoditas yang potensial dimanfaatkan untuk meningkatkan kinerja ekspor Indonesia. Berdasarkan hasil penelitian dengan mempertimbangkan analisis daya saing, komoditas lada Indonesia memiliki potensi pengembangan pasar optimis di pasar Belanda. Sedangkan pasar potensial bagi ekspor komoditas ini adalah pasar Malaysia, Vietnam, Korea Selatan, Rusia, Prancis, Belgia, Jerman, dan Amerika Serikat. Maka apabila pemerintah dan eksportir akan melakukan pengembangan ekspor komoditas lada sebaiknya pemerintah dan eksportir mengutamakan pengembangan ke pasar Belanda. 
Adapun prioritas kedua pengembangan ekspor komoditas lada sebaiknya ditujukan ke pasar potensial, yaitu Malaysia, Vietnam, Korea Selatan, Rusia, Prancis, Belgia, Jerman, dan Amerika Serikat.

Adapun faktor-faktor yang berpengaruh signifikan terhadap ekspor komoditas lada adalah produk domestik bruto per kapita, populasi, harga ekspor, jarak ekonomi dan tarif negara tujuan. Maka untuk melakukan pengembangan ekspor lada Indonesia ke pasar lain, sebaiknya pemerintah dan eksportir mempertimbangkan faktor-faktor yang memengaruhi ekspor lada tersebut. Adapun kebijakan yang dapat diambil adalah dengan menjaga stabilitas harga ekspor dan memilih pasar dengan PDB per kapita dan populasi yang besar dan cenderung meningkat dari tahun ke tahun, serta memiliki jarak ekonomi dan tarif yang kecil dan cenderung menurun dari tahun ke tahun.

\section{UCAPAN TERIMA KASIH}

Puji dan syukur penulis ucapkan kehadirat Allah YME sehingga penulis dapat menyelesaikan artikel ini. Pada kesempatan ini penulis juga mengucapkan terima kasih kepada para dosen, staf dan civitas akademika Program Studi Magister Sains IImu
Ekonomi FEM IPB dan Sekolah Pascasarjana IPB yang telah memberikan dukungan \& bimbingan kepada penulis. Semoga penelitian ini dapat bermanfaat bagi banyak pihak.

\section{DAFTAR PUSTAKA}

Andari, W. (2017). Analisis Pengaruh dan Tingkat Keberhasilan Perdagangan Indonesia dalam ASEAN-India Free Trade Agreement (AIFTA). Thesis. Bogor: Institut Pertanian Bogor.

Departemen Pertanian RI. (2009). Pedoman Teknis Pengembangan Lada Organik. Diunduh tanggal 6 Mei 2018 dari pusdatin.setjen.pertanian.go.id/

Estherhuizen, D. (2006). An Evaluation of The Competitiveness of the South African Agribusiness Sector. Journal University of Pretoria.

Hasibuan, A.M., Rita, N., Agus, W. (2012). Analisis Kinerja dan Daya Saing Perdagangan Biji Kakao dan Produk Kakao Olahan Indonesia di Pasar Internasional. Buletin Risti. Vol3(1), pp.57-70.

Inayah, I., Oktaviani, R., Heny, K.D. (2015). The Analysis of Export Determinant of Indonesian Pepper in the International Market. International Journal of Science and Research (IJSR). Vol.5 (11), pp. 1856-1860.

Irgandhini, A.K., Firdaus, M. (2014). Daya Saing Dan Permintaan Ekspor Produk Biofarmaka Indonesia Di Negara Tujuan Utama Periode 2003-2012. Jurnal Manajemen dan Agribisnis. Vol.11(3), pp. 183-198.

Jordan, A. (2014). Factors that Affect Jordan's Exports during the Period (2003-2012). International Journal of Business and Social Science. Vol.5(6), pp. 115-121.

Juanda, B., Junaidi. (2012). Ekonometrika Deret Waktu (Teori dan Aplikasi). Bogor : IPB Press. 
Kementerian Perdagangan RI. (2013). Kajian Potensi Pengembangan Ekspor ke Pasar Non Tradisional. Jakarta:Pusat Perdagangan Luar Negeri, BP2KP

Kementerian Perdagangan RI. (2014). Analisis Dampak Implementasi Environmental Goods List (EG List) dan Identiikasi Development Products terhadap Kinerja Perdagangan. Diunduh tanggal 6 Juli 2018 dari http://www.Kementerian

Perdagangan RI.go.id/

Kementerian Perdagangan RI. (2017). Kementerian Perdagangan RI: Negara Tujuan Ekspor 10 Komoditas Potensial. Diunduh tanggal 13 April 2017 dari http://www.Kementerian Perdagangan Rl.go.id/ id/economicprofile/10-main-and-potentialcommodities/10potential commodities.

Kementerian Pertanian RI. (2013). Pedoman Teknis Pengembangan Tanaman Lada Tahun 2014. Diunduh tanggal 6 Mei 2018 dari pusdatin.setjen.pertanian.go.id/

Kementerian Pertanian RI. (2015). Outlook Lada Komoditas Pertanian Subsektor Perkebunan. Diunduh tanggal 27 April 2018 pusdatin.setjen.pertanian.go.id/

Kementerian Pertanian RI. (2017). Data Produksi Rempah Unggulan Indonesia. Diunduh tanggal 6 April
2017

dari aplikasi.pertanian.go.id/bdsp/newdat a.

Kis-Katos, K., Sparrow, R. (2015). Poverty, labour markets and trade liberalization in Indonesia. Journal of Development Economics. Vol.3878 (15), pp.1-45.

Maulana A, Kartiasih. (2017). Analisis ekspor kakao olahan Indonesia ke sembilan negara tujuan tahun 20002014. Jurnal Ekonomi dan Pembangunan Indonesia. Vol.17(2), pp. 103-117.

Nicholson, W. (2002). Microeconomic Theory Basic Principles and Extensions. New York : Harcort Brace Colege Publisher.

Ningsih, A. (2013). Analisis Daya Saing dan Faktor-aktor yang Memengaruhi Permintaan Minyak Atsiri Indonesia di Negara Tujuan Ekspor. Skripsi. Bogor : Institut Pertanian Bogor.

Pindyck, R.S., Rubenfield, D.L. (2009). Microeconomics, [7th Edition]. New Jersey (USA): Pearson Education, Inc.

Suryana, A.T., Fariyanti, A., Rifin, A. (2014). Analisis perdagangan kakao Indonesia di pasar internasional. Jurnal TIDP. Vol.1(1), pp.29-40.

UN-Comtrade. (2018). Sumber dari Internet Tentang Statistics Database. Diunduh tanggal 13 April 2018 dari https://comtrade.un.org/data. 